\title{
Tahapan Proses Pengambilan Keputusan Warga RW 19 Dukuh Sukunan dalam Mengadopsi Inovasi Pengelolaan Sampah Mandiri Rumah Tangga
}

\author{
Christina Nur Wijayanti, Jeratallah Aram Dhani2 \\ Program Studi Ilmu Komunikasi, Fakultas Ilmu Sosial dan Ilmu Poliltik \\ Universitas Surakarta \\ wijayantichristina@gmail.com1,j.arramdhani@yahoo.co.id2
}

\begin{abstract}
ABSTRAK
Dukuh Sukunan menjadi pelopor program pengelolaan sampah mandiri rumah tangga yang dirintis mulai dari tahun 2002 dan akhirnya mendapatkan pengukuhan dari pemerintah dengan dicanangkan sebagai desa wisata lingkungan tahun 2009. Keberhasilan warga Dukuh Sukunan dalam mengadopsi inovasi sehingga menciptakan pembaruan inilah yang menarik untuk dilihat. Penelitian ini dilakukan untuk mengetahui bagaimana tahapan proses pengambilan keputusan Warga RW 19 Dukuh Sukunan dalam mengadopsi inovasi pengelolaan sampah mandiri rumah tangga. Jenis penelitian ini merupakan penelitian deskriptif kualitatif. Sumber data dalam penelitian ini adalah primer dan sekunder. Teknik pengumpulan datanya adalah dengan teknik wawancara dan observasi, untuk cara menentukan sampelnya menggunakan teknik purpossive sampling.

Hasil dari penelitian menunjukkan bahwa terjadi loncatan dalam tahapan pengambilan keputusan inovasi di Sukunan yaitu (1) tahap implementasi, (2) tahap pengetahuan, (3) tahap persuasi, (4) tahap pengambilan keputusan, dan (5) tahap konfirmasi.
\end{abstract}

Kata kunci: difusi inovasi, tahap pengambilan keputusan, pengelolaan sampah mandiri

\begin{abstract}
Sukunan village becomes pioneer of the independent of household waste management program which is started since 2002 and finally, the village becomes environment tourism village in 2009. The successful of Sukunan village inhabitant in communicate this innovation until create this invention is interesting to be seen closer. This research was conducted to find out how the stages of the decision-making process of RW 19 Dukuh Sukunan in adopting household independet waste management innovations. The research is used innovation adoptions diffusion theory by Everett $M$. Rogers. The research is qualitative research with case study research. The research uses a deep interview and an observation method to collect the data. The sample data which is used in this research is got by purposive sampling data. To analyze the data, it is used interactive analysis. The results of the study showed that there wa a jump in a stages of innovation decision making in Sukunan, namely (1) implementation phase, (2) knowledge phase, (3) persuasion stage, (4) decison making stage, (5) and confirmastion stage.
\end{abstract}


Key words: diffusion of innovation, independent of household waste management, decision making process.

\section{PENDAHULUAN}

Permasalahan lingkungan hidup dan laju kerusakan dan pencemaran lingkungan semakin hari semakin meningkat. Persoalan lingkungan diantaranya adalah pengelolaan sampah karena menyangkut masyarakat luas dan jika tidak dikelola dengan baik dapat menimbulkan dampak yang serius. Pengelolaan sampah yang tidak baik ini biasa dialami oleh setiap desa maupun kota. Akan tetapi berawal dari sebuah kebiasaan pengelolaan sampah yang tidak teratur ini, Dukuh Sukunan, Kelurahan Banyuraden, Kecamatan Gamping, Sleman menciptakan sebuah konsep dalam pengelolaan sampah mandiri rumah tangga. Ide yang dipelopori oleh Iswanto yang adalah seorang pendatang ini menjadi sebuah inovasi karena merupakan sebuah ide baru yang belum pernah ada sebelumnya.

Pengelolaan sampah mandiri ini selain menciptakan kebiasaan baru yang produktif bagi warga desa juga menciptakan penghasilan sampingan bagi warga desa. Sampah yang semula tidak bernilai ekonomi, setelah dikelola baik dengan dijual ke pengepul maupun diolah kembali menjadi memiliki nilai ekonomi yang lebih sehingga menguntungkan warga desa. Dengan prinsip $3 \mathrm{R}$ yakni reduce, reuse, dan recycle, warga Dukuh Sukunan berupaya menjadikan Desa Sukunan menjadi desa yang ramah lingkungan. Usaha yang dirintis sejak tahun 2003 ini akhirnya membuahkan hasil dengan dicanangkannya Dukuh Sukunan sebagai desa Wisata Lingkungan pada 19 Januari 2009.

Sistem Pengelolaan Sampah Mandiri Rumah Tangga yang berprinsip $3 \mathrm{R}$ ini dikategorikan inovasi karena sesuai dengan definisi-definisai inovasi oleh para ahli yang memenuhi persyaratan "baru" dan merupakan sebuah ide dari seseorang. Sedangkan kebaruan di sini memenuhi salah satu kriteria inovasi yang diungkapkan oleh Sudikno (dalam Sutopo, 1986:23-24) dimana sesuatu dikatakan baru apabila menciptakan sesuatu yang baru, yang sebelumnya belum ada. Sistem ini dibuat terintegrasi sehingga menciptakan sistem pengelolaan sampah rumah tangga mandiri.

Sebuah temuan ataupun hal baru yang diciptakan oleh manusia yang sering disebut sebagai inovasi, agar bisa digunakan dan dinikmati oleh orang banyak memerlukan komunikasi dalam penyebarannya. Dalam hal penyebaran inilah komunikasi sangat diperlukan oleh si penemu tersebut. Bagaimana warganya mengelola komunikasi dan jaringan sehingga berhasil mengubah kebiasaan warga yang tidak baik menjadi kebiasaan yang ramah lingkungan. Dalam mengadopsi dan pada akhirnya mengimplementasikan sebuah hal dan program yang baru yang merupakan sebuah inovasi membutuhkan sebuah tahapan yang lama. Hal inilah yang kemudian membuat peneliti tertarik untuk meneliti bagaimana proses tahapan pengambilan keputusan inovasi pengeloalan sampah mandiri rumah tangga di Dukuh Sukunan sehingga warga Dukuh Sukunan secara menyeluruh menngadopsi inovasi pengelolaaan sampah mandiri rumah tangga ini. 


\section{METODOLOGI PENELITIAN}

Berdasarkan pada permasalahan yang diajukan dalam penelitian ini, maka penelitian yang dilaksanakan adalah penelitian kualitatif. Adapun jenis penelitian adalah penelitian deskriptif yang menggambarkan dan mencermati fenomena sosial tertentu dengan mengembangkan konsep dan menghimpun fakta tanpa menguji hipotesa.

Data dan informasi yang dikumpukan dalam penelitian ini adalah data kualitatif. Penelitian ini memakai teknik pengambilan sampel bersifat purposive atau sering disebut purposive sampling/sampling bertujuan (Moleong, 2008). Teknik pengambilan data dilakukan dengan wawancara, observasi dan juga mengambil data dari dokumen-dokumen.

Model analisis yang digunakan adalah analisis data yang diungkapkan Miles dan Huberman. Terdapat 3 jalur analisis data kualitatif, yaitu reduksi data, penyajian data dan penarikan kesimpulan (Miles dan Huberman, 1992).

\section{KAJIAN PUSTAKA \\ Difusi Inovasi}

Menurut Rogers (2003 : 194) diffusion is the process in which an innovation is communicated through certain channels over time among the members of a social system. Pemahaman Rogers mengenai difusi ini adalah merupakan sebuah proses dimana sebuah inovasi dikomunikasikan melalui saluran-saluran tertentu dari waktu ke waktu di antara anggota masyarakat. Dari pengertian tersebut mengandung 4 elemen dalam dalam inovasi, yaitu (1) inovasi, (2) saluran komunikasi, (3) waktu, dan (4) sistem sosial.

1) Inovasi

Dalam buku edisi kelimanya, Rogers mengungkapkan kembali pengertian inovasi. Menurut Rogers (2003 : 220) an innovation is an idea, practice, or object that is perceived as new by an individual or other unit of adoption. Rogers mengartikan inovasi sebagai: ide-ide baru, praktek-praktek baru, atau obyek-obyek yang dapat dirasakan sebagai sesuatu yang baru oleh individu atau masyarakat sasaran penyuluhan Sedangkan Loinberger dan Gwin (1982) yang dikutip oleh Totok Mardikanto mengartikan inovasi tidak sekedar sebagai sesuatu yang baru, tetapi lebih luas dari itu, yakni sesuatu yang dinilai baru atau dapat mendorong terjadinya pembaharuan dalam masyarakat atau pada lokalitas tertentu (Mardikanto, 2010 : 113).

Dari pengertian yang diungkapkan oleh para tokoh tersebut di atas mengandung pemahaman bahwa inovasi tidak hanya sekedar terbatas pada sebuah benda ataupun teknologi hasil dari kerja manusia, akan tetapi juga termasuk di dalamnya ideologi, sikap hidup, informasi, pola pikir, perilaku bahkan dapat berupa gerakan atau program yang bertujuan untuk membuat perubahan di dalam tata kehidupan masyarakat dan yang pasti bersifat "baru". Sifat baru ini tidak harus dari hasil penelitian yang mutakhir. Namun baru di sini dinilai dari sudut pandang penilaian individu yang menggunakannya yakni masyarakat sebagai adopternya. 


\section{2) Saluran Komunikasi}

Menurut Rogers (2003 : 268) A communication channel is the means by which messages get from one individual to another. Saluran komunikasi adalah 'alat' untuk menyampaikan pesan-pesan inovasi dari sumber kepada penerima. Dalam memilih saluran komunikasi, sumber paling tidak, perlu memperhatikan (a) tujuan diadakannya komunikasi dan (b) karakteristik penerima.

3) Waktu

Dimensi waktu yang terlibat dalam difusi (1) proses pengambilan keputusan inovasi yang mana seorang individu melewati dari pengetahuan pertama dari sebuah inovasi sampai adopsi atau penolakan, (2) inovasi dari individu atau unit adopsi lainnya (yaitu, tingkat relatif awal/terlambat dimana sebuah inovasi diadopsi) dibandingkan dengan anggota lain dari sistem, dan (3) tingkat sebuah inovasi yang adopsi dalam suatu sistem, biasanya diukur sebagai jumlah anggota dari sistem yang mengadopsi inovasi dalam jangka waktu tertentu (Rogers, 2003:225).

\section{4) Sistem Sosial}

Sebuah sistem sosial didefinisikan sebagai satu set unit yang saling terkait yang terlibat dalam pemecahan masalah bersama untuk mencapai tujuan bersama. Para anggota atau unit sistem sosial dapat berupa individu, kelompok informal, organisasi, dan / atau subsistem (Rogers, 2003:217)

\section{Adopsi Inovasi}

Dalam bukunya Komunikasi Pembangunan, Totok Mardianto mengemukakan pendapatnya mengenai Adopsi. Menurutnya, adopsi pada hakekatnya diartikan sebagai proses penerimaan inovasi dan atau perubahan perilaku baik yang berupa: pengetahuan (cognitive), sikap (affective), maupun ketrampilan (psychomotoric) pada diri seseorang setelah menerima "inovasi" yang disampaikan fasilitator oleh masyarakat penerima manfaatnya (Mardikanto, $2010: 137)$.

Menurut Rogers (2003 : 1099), tahapan proses pengambilan keputusan inovasi meliputi:

1. Tahap pengetahuan

Pengetahuan terjadi ketika seorang individu (atau pengambilan keputusan unit) terkena keberadaan suatu inovasi dan mendapatkan suatu pemahaman tentang bagaimana fungsinya.

2. Tahap persuasi

Persuasi terjadi ketika seorang individu (atau pengambilan keputusan unit) membentuk sikap yang menguntungkan atau tidak menguntungkan terhadap inovasi.

3. Tahap Pengambilan Keputusan

Keputusan terjadi ketika seorang individu (atau pengambilan keputusan unit) terlibat dalam kegiatan-kegiatan yang mengarah pada pilihan untuk mengadopsi atau menolak inovasi.

4. Tahap Implementasi

Implementasi terjadi ketika seorang individu (atau pengambilan keputusan unit) menempatkan ide baru untuk mulai digunakan. 


\section{Tahap Konfirmasi}

Konfirmasi terjadi ketika seorang individu mencari penguatan keputusan inovasi.

\section{Sistem Pengelolaan Sampah}

Menurut UU No. 18 Tahun 2008 pengelolaan sampah didefinisikan sebagai kegiatan yang sistematis, menyeluruh, dan berkesinambungan yang meliputi pengurangan dan penanganan sampah.

Pengelolaan sampah yang umum terjadi saat ini adalah memisahkan antara sampah organik dan sampah anorganik. Kemudian proses selanjutnya adalah pengolahan sampah organik ini (biasanya rumah tangga) untuk pupuk pertanian.

Beberapa sistem pengelolaan sampah yang ada di Indonesia (Marlina, Aliyah, Hardiana, 2007:13-14):

1) Pengumpulan sampah permukiman sederhana.

2) Penumpukan sampah secara liar (open dumping).

3) Penumpukan sampah secara terkontrol.

4) Pembakaran sampah.

\section{HASIL DAN PEMBAHASAN}

\section{Proses Difusi Adopsi Inovasi Pengelolaan Sampah Mandiri Rumah Tangga Warga RW 19 Dukuh Sukukan}

Warga Dukuh Sukunan yang merupakan warga pedesaaan masih menjunjung tinggi norma-norma kerukunan, solidaritas dan menghargai serta peduli keberadaan orang lain. Norma-norma yang mereka yakini inilah yang membawa mereka pada perilaku untuk selalu menjalin komunikasi dan interaksi mereka dengan orang lain baik itu dilakukan dalam taraf interpersonal maupun dalam kelompok. Hal ini terlihat dalam perilaku mereka sehari-hari seperti ketika bertemu dengan tetangga atau pun orang lain selalu saling menyapa, terlibat pembicaraan mengenai kehidupan sehari-hari maupum gosip atau informasi terbaru setiap kali bertemu dalam kelompok ketetanggaan. Interaksi mereka dalam kelompok ketetanggan ini memperlihatkan adanya norma kerukunan yang mereka wujudkan dalam pergaulan.

Terdapat dua pola komunikasi warga yang menonjol dalam proses difusi adopsi inovasi pengelolaan sampah mandiri rumah tangga ini yaitu pola komunikasi interpersonal dan pola komunikasi kelompok. Sedangkan untuk komunikasi massa, warga Dukuh Sukunan kurang melakukan aktivitas komunikasi massa, dimana mereka kurang mengakses media massa.

Pada pola komunikasi interpersonal masyarakat lebih banyak melibatkan sumber informasi dari warga sendiri baik keluarga (Ayah, Ibu, Anak), kerabat, maupun tetangga. Pesan yang diperbincangkan adalah segala sesuatu yang berkaitan dengan kehidupan sehari-hari, keluarga, dan juga informasi terbaru seputar dukuh mereka, dalam hal ini 
adalah inovasi pengelolaan sampah mandiri rumah tangga. Komunikasi ini berjalan dua arah dan terjadi di mana pun dan kapan pun mereka bertemu.

Sedangkan komunikasi kelompok baik formal maupun informal yang terjadi menunjukkan perbincangan rutin masalah kampung dan juga program-program terbaru yang muncul di kampung, dalam hal ini adalah sistem pengelolaan sampah mandiri rumah tangga. Pertemuan-pertemuan kelompok ini terjadi antara lain dalam pertemuan paguyuban BERSEMI, pertemuan RT/RW, pertemuan kelompok ronda, dan juga perbincangan dalam kelompok-kelompok ketetanggaan. Diskusi yang terjadi dalam kelompok ronda menjadi awal mula munculnya ide inovasi sistem pengelolaan sampah mandiri rumah tangga. Hal ini dapat diketahui dari kesaksian yang diungkapkan oleh Iswanto (wawancara 07 Desember 2013) yang menyatakan bahwa kelompok ronda dijadikan anggotanya tempat berkeluh kesah, seperti dalam hal ini adalah masalah sampah yang dialami oleh warga petani. Bermula dari keluh kesah petani yang adalah anggota kelompok ronda, muncul solusi berupa inovasi pengelolaan sampah mandiri rumah tangga. Dalam kelompok ini para pelopor awal program ini mendiskusikan mengenai segala sesuatu yang berhubungan dengan pengelolaan sampah mandiri rumah tangga. Berbeda dengan diskusi yang dilakukan dalam pertemuan formal seperti pertemuan RT/RW dimana pertemuan ini dijadikan sarana sosialisasi oleh para pelopor sistem pengelolaan sampah mandiri yang kemudian memiliki paguyuban dengan nama BERSEMI.

Warga Dukuh Sukunan kurang mengakses media massa baik cetak (koran, majalah, tabloid) maupun elektronik (televisi dan radio) untuk memperoleh informasi yang berhubungan dengan sistem pengelolaan sampah mandiri rumah tangga. Media massalah yang menyebarkan informasi mengenai sistem pengelolaan sampah mandiri rumah tangga ini kepada warga di luar Sukunan.

\section{Tahap Pengetahuan}

Dalam tahap awal (pengetahuan) yang menjadi pemeran utama dalam penyebaran pesan (informasi) tentang pengelolaan sampah rumah tangga mandiri adalah Iswanto. Iswanto melakukan komunikasi interpersonal dengan para anggota kelompok ronda. Anggota kelompok yang menerima informasi (pesan) tentang pengelolaan sampah rumah tangga ini dengan cepat menerima inovasi yang disampaikan kepada mereka. Hal ini dikarenakan informasi (pesan) yang mereka terima secara relatif mendekati pandangan mereka sendiri. Hal ini disebabkan karena anggota kelompok ronda inilah yang mengemukakan permasalahan sampah. Berlatar belakang permasalahan inilah Iswanto dan anggota kelompok ronda mencari solusi untuk permasalahan sampah di Sukunan sehingga memunculkan inovasi pengelolaan sampah mandiri rumah tangga. Dengan persamaan pandangan inilah tahap awal (pengetahuan) sistem pengelolaan sampah mandiri rumah tangga mudah diterima oleh anggotanya.

\section{Tahap Persuasi dan Pengambilan Keputusan}

Dalam tahap selanjutnya yaitu tahap persuasi dan pengambilan keputusan lebih dialami oleh warga Sukunan yang menjadi keluarga atau tetangga dekat para pelopor awal (kelompok ronda). Baik istri maupun para tetangga ini menerima informasi (pesan) 
tentang pengelolaan sampah rumah tangga mandiri melalui obrolan/percakapan yang mereka lakukan sehari-hari. Informasi (pesan) yang mereka terima ini tidak serta merta mereka terima begitu saja. Mereka memiliki acuan atau pandangan (argumen) sendiri mengenai permasalahan sampah ini. Mereka masih memiliki pemahaman bahwa sampah itu dibakar atau dibuang ke sungai. Untuk meyakinkan keluarga dan tetangga terdekat membutuhkan usaha yang keras dan gigih. Tidak hanya pesan secara verbal (perkataan), akan tetapi pesan non verbal (contoh tindakan) juga dilakukan.

\section{Tahap Implementasi dan Konfirmasi}

Selanjutnya setelah memutuskan untuk menerima inovasi pengelolaan sampah rumah tangga mandiri ini mereka melakukan program ini seperti pemilahan sampah, membuat dan memakai komposter sederhana, dan penggunaan ulang (reuse) sampah yang masih bisa diolah seperti plastik dan kertas di dalam rumah tangga mereka masingmasing. Ketika akhirnya menerima dan melakukan pengelolaan sampah rumah tangga mandiri ini, warga tetap melakukan komunikasi interpersonal dengan warga lainnya (keluarga, kerabat, tetangga, tokoh masyarakat) untuk mengetahui lebih dalam inovasi yang mereka jalankan ini. Selain itu, komunikasi interpersonal yang dilakukan juga dilakukan untuk lebih memantapkan keputusan mereka apakah keputusan mereka benar atau salah jika mengadopsi sistem pengelolaan sampah rumah tangga mandiri ini. Ini termasuk dalam tahap konfirmasi. Warga mencari penguatan atas keputusan mereka.

\section{Simpulan}

Dari hasil data di lapangan dan hasil pembahasan, terjadi loncatan dalam tahap pengambilan keputusan inovasi pengelolaan sampah mandiri rumah tangga di Dukuh Sukunan. Baik mulai dari inovator awal sampai kepada unit penerima inovasi (adopter) mengalami loncatan tahap. Menurut teori, proses pengambilan keputusan inovasi terdiri dari 5 tahap sebagai berikut:

1. Tahap Pengetahuan

2. Tahap Persuasi

3. Tahap Pengambilan Keputusan

4. Tahap Implementasi

5. Tahap Konfirmasi

Sedangkan dari temuan data di lapangan, tahapan pengambilan keputusan inovasi yang terjadi di Dukuh Sukunan adalah sebagai berikut:

1. Tahap Implementasi

2. Tahap Pengetahuan

3. Tahap Persuasi

4. Tahap Pengambilan Keputusan

5. Tahap Konfirmasi

\section{DAFTAR PUSTAKA}

Cangara, Hafied. 2011. Pengantar Ilmu Komunikasi. Jakarta: Mutiara. 
JK, Sutopo. 1986. Komunikasi Pembangunan dan Komunikasi Kependudukan. Surakarta: Fakultas Ilmu Sosial dan Ilmu Politik Universitas Sebelas Maret.

Littlejohn, Stephen W. 2008. Theories of Human Communication (Ninth Edition). Belmont, CA: Wadsworth.

Mardikanto, Totok. 2010. Komunikasi Pembangunan. Surakarta: UPT Penerbitan dan Percetakan UNS.

Marlina, Avi, Alioyah, Istijabatul, Hardiana Ana. 2007. Penataan Tempat Pembuangan Sementara (TPS) Sampah Rumah Tangga Kawasan PErumahan Jaten PErmai Indah Di Kabupaten Karanganyar. Laporan Penelitian. DIPA PNBP LPPM UNS.

Miles, MB dan AM Huberman. 1992. Qualitative Data Analysis: A Sourcebook of New Methods. Beverly Hills: SAGE.

Moleong, Lexy J. 2008. Metode Penelitian Kualitatif. Bandung: PT. BPK Gunung Mulia.

Mulyana, Deddy. 2002. Ilmu Komunikasi: Suatu Pengantar. Bandung: Remaja Rosdakarya.

Rogers, Everret M. 2003. Diffusion of Innovations Third Edition. New York: The Free Press.

Undang-Undang No. 18 Tahun 2008 